\title{
A Critical Review of Existing Approaches to Siberia: Relevance to Siberian Economic Development
}

\author{
IK JOONG YOIN ${ }^{* *}$ AND BERNHARD SEIIGER ***
}

\begin{abstract}
Russic went through major political and conomic changes in the 1990s. Sitheric, histurically it resuurce-colony, also began autonunious ecinomic bevelopmont. I lowever, cconomic development died not succeed as plannec! and resuled in total failure. Siberia

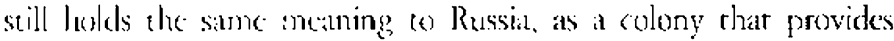
natural resources. But the exploitation of Siberia's rich resources is not enough to entice policynakers and scientists to develop Siberia until it raaches its tull economic potential. 'I'his leads to a concentration of research in the economic analysis of resources, conergy, transport, envitonmens, agriculeurc, and forestry. The focus on institutional transtomination is very typical in the discussion about Contral Lurope, Fastcrn Furopx; and Russias transformation, while micro-institutional analyses semain silent ahout Siberia. Ennerging research on fiscal fedcralism and regionalization in Russia can provide basic elements of a micro-institutional theory, but elements such as a framework for education, local administration, and infrastructure are still wanting.
\end{abstract}

Keyands: Siberia, economic development, micro-institutional factors, resource economies, resource colony, regional cconomy

\footnotetext{
This pilper has been supported by dhe Kusea Restagch foundation (KRF 2002.07\%.BM2076).

10. First author. Direst all correspor.denre to lk Joong Youn, Assistant Protessor. Department of International Relations, Hallym Inscitute of Advanced Incernational Studies, 906-18 Daechi-tong,

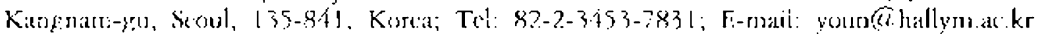

* Bernharé Scliger, Dirceter. Hatnns Scidel Foundation, Seoul Office, 50!. Sio Young Bldg. 64-1

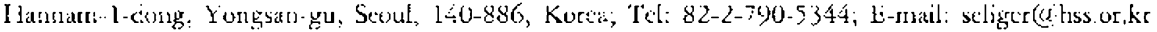




\section{INTRODUCTION}

R ussia went through major political and cconomic changes in the 1990s. Siberia, R historically a rcsource-colony, also began autonomous cconomic development. The changes in the center seemed to announce a new Russia integrated in the trend of globalization with the potential to catch up with the Western world cconomy. Russia was also reaping the fruits of the peace dividend of rcduccd military spending, trying to become a respected and valued partner in the Western world. The regional changes seemed to install a new system of federalism, voluntary organization with free access, participation, and even secession possibilities. As described by Boris Yeltsin, "grabbing as much power as they can" seemed to be the most suitable description for Russia at that time. The implications for Siberia were voiced by Michael Bradshaw (1992), who saw a number of desideration for Siberian development, including: a fair share of resources in the "new Siberian resource bonanza"; a rejuvenation of resource industries; Siberia's full cconomic sovereignty; a new political status of auronomy (as part of federal system); and a regional economic strategy, balancing regional and central interests. ${ }^{1}$

As part of the Russian Federation, Siberia had to live with two disappointments. First, the process of Russia's economic transformation proved to be much harder than expected, developing into a chain of smaller and bigger political and economic crises and severely restricting the implementation of new economic and regional policies. Russia experienced a dramatic fall in living standards and even severe problems of poverty, far more extreme than in the other transitioning countries in Contral and Easteru Europe. ${ }^{2}$ Second, the political crisis also affected the emerging federal structure, going through a phase of "chaotic fedcralism" in which competences were allocated according to the strongest. Hopes for balancing regional and central interests (see Schneider 2000) ended during the period of virtual re-centralization under Putin, which was widely approved as an instrument to end the former chans.

Siberia's position today still remains that of a resource colony, even with changes in the political power structure (it would be misleading to speak of the installation of a democracy in the Western sense, especially at the regional level) and the introduction of a specific form of market economy. ${ }^{3}$ This is also handled in research on Siberia, focusing on Siberian issues in business, politics, and science. In both domestic and international business, the focus is rational, as profits can mostly be cxpected by exploiting Siberia's rich resources that also lead a clear dircction for business rescarch. ${ }^{4}$ For policymakers and scientists who were eager to develop Siberia's full economic potential, it is crucial to bave additional interest in regional development beyond resourse exploitation.

It is interesting that non-Russian, Western research focuses on geopolitical and geo-economic concerns over Siberia and its resources. The focus, however, did not change throughout the 1990s and did not touch on domestic economic development. This leads to a concentration of research in the economic analysis of resources, 
energy, transport, environment, agriculture, and forestry. The focus on institutional transformation so typical for the discussion of transformation of Central and Eastcrn Europe and Russia as a whole did not emerge. Thus, a micro-institutional analysis of Siberian development remains missing. Fmerging research on fiscal federalism and regionalization in Russia can provide basic clements of such a micro-insticutional theory. Other elements, such as a framework for cducation, local administration, and infrastructure need to be added.

This paper reviews Western approaches to Sibcria's economic development in the above-mentioned fields. ${ }^{5}$ The contribution of these research approaches to Sibcrian economic development is analyzed, followed by a less prominent discussion. They are important institutional factors for Siberian economic devclopment (Section 3). The paper concludes with a new research agenda that will be helpful to Siberia as an cmerging cconomic region, integrated into the greater Russian and Northeast Asian economic arenas (Section 4).

\section{EXISTING (WESTERN) APPROACHES TO ECONOMIC DEVELOPMENT IN SIBERIA}

In 1994, under the title of America's Earth Day supergift: Siberia, an author described Siberia in a drastic manner, one that many orhers would agree upon albeic less drastically.

\footnotetext{
"Like the American West of the 1800 s, Siberia's entimment is threatened b; reckless economic development. Lake Baikal and the Angara River are dying from pollution. soil erosion is destroying agricultural land, air pollution is poisoning the people, and toxic mining wastes are simply damped. Russia lak the twhology. expertise and will to protect entimnmental values. Pinerty and hardsbip encourage extensize logging: mining and strilling with little thousht for the long-term consequences. Responsible managsment by the nonprofit and for profit sators pronides the path to responsible aremess. This requives institutions that provide incentives to consider enology and community as well as eionomic values. I recommend we onate a public. quasi-gowcmmonal compomation is purbise Siberia from Rawsia." (Baden 1994)
}

This description of Siberia points out some of the region's problems but focuses on Siberia as a resource colony in two distinct respects. The focus is on resources, not on regional development and corresponding solutions; a "quasi-governmental" organization is again centralized and statc-led, rather than incorporating a decentralized approach. This is the approach to Siberia that will prevail in Western and Russian thinking alike. For example, a Russian source formulates the problem as follows: 
At present Siberia excesds the national her cupict gross domestic produt nise than 1.2 limes. This puts it tis one of the leadins places in

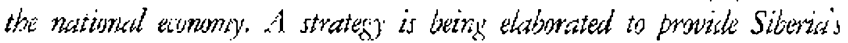
attive role in shluing the nationd tabks. supplying the needs of Russiats domestic market and exporting its resouries; creation in Siberia by the year 2020 of a self suffeitent interyted econsmy as a purt of the common national econtismic spare and providing comfortable hab isation and bigh living standards for its intabitanti. These tasks can be jullilled with gremmental participation in a number of dirations of priority. primarily in elaboration and adsption of lexilativin suppont-

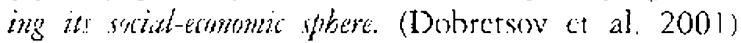

Both the Russian and US cases mention the importance of a regional approach (community approach" in the first, "self-sufficient integrated economy" in the second), as well as an institutional approach (Institurions that provide incentives" in the first, "legislation supporting its social-eronomic sphere" in the second). The focus on resources and on a centralized development plan became clear. This is not a coincidence, but is a common vicuposint for much research on Siberia's economic development. 'Ihe following paragraphs illustrate some of the dominant questions resulting from this viewpoint.

The first large group of publications concem Siberia's resurces, their extension and development.' $A$ number of them discusses the state of Siberian resources (see Karrasch 1995 and especially the bithliography of Murray 1997a), the geo-politicil role of these resources (see Klïter 1994; Dienes et al. 1994; and Murray and Bradshaw 1997), and Siberia's development chances due to its rich endowment of natural resources (Bradshaw and Lynn 1996; 1.ynn 1996). Oil and gas are the two resources that gain the most atcention in Siberian economic development. The numerous studies on Russia's oil and gas industry include scctoral overviews (see Astrov 2003), studies on the state of the gas industry (Biggrat 2002 and Wein 1996a, 1996b specifically on Western Siberia) and the oil industry (Considine and Kerr 2002; Sagers 2001), gas sector policy (Locatelli 2002), oil sector policy (Iane 1999), the development of large, internationally important companies in the field (Liutho 2001), and sub-regional studies focusing on Western Siberia, Eastern Siberia, or the Ear East (Sagers 19953. Reviewed litcrature include works on the geo-economic importance of Russian energy (Morse and Richard 2002) and all issues related to foreign legal (Shulga 200)1; and political (Heinrich et al. 2002) aspects.

Resources apart from the energy sector form a part of Siberia's rich endowment and gained the attention of the researchers (see Bond and Levine 2001) for the nickel and platinum industry. Among these resources, the forest sector is ultimately the most important factor. Sibcria accounts for $10 \%$ of Russian forest resources. Russia accounts for one-half of the world's coniferous forcsts. As a global supplier, 
environmental resources are very important. the economic irspact and development possibility of Siberia's forests (see Gerloff 199/4; Murray 1997b; Obersteiner 1998a; Backmann and Zausaev 1998; Backmann 1999) have important cnvironmental implications. As such, a large project named the Siberian Forest Study was carried out by the International Institute for Applied Systems Analysis, or IIASA (see, for example, Blauberg 1995; Obcrsteinct 1995, 1998b; Nilsson et al. 1996). While of lesser interest, fisheries (see Murray $1997 \mathrm{~b}$ and the case study of Wilson 2002) and agriculture (see the case studies of Tanneberger 1997 for Western Siberia; Bychkova ot al. 1998 for the Far East) are also investiaged in the research.

One of the gravest problems resulting from Siberia's status as a resurce-tich region is the overexploitation of resources and the possibility of pollution. A number of scientific: studies took place but NGOs based in the West are active in studying pollution and ways to overcome cnvironmental problems. One of the foremost problems is the exact measurement of the ecolngrical state in regional studies (sec Flück 1996 and Wein 2002 for the Baikal region) or in measuring the ecological impact of Siberia for the world climate, alongside the Central Siberian forest project (Schmullius and Wagner 2000; European Space Agency 2003).

Land use among natives and industry is another important issue (Forbes 1994; Habeck 2002; Zikes 2002; Frühauf and Meinel 2003). Sectoral environmental problems, especially in the oil industsy, are analyzed and new market-compatible solutions proposed (Smirnov 19)/ Gavigan 19)6). Nuclear waste related to mining and the military is another specific problem (Robinson and Cook 1995; Bøhmer and Nilsen 1995; American Lniversity 1996a, 1996b). NGOs focus on the roles and potential of Siberiais new ecological movement (see the issue devoted to the Siberian ecological movement of Gite and Take, ISAR 2003). The chances of developmental aid in the field of environment are also discussed (Opp and Haase 2000).

Siberia's environmental problems can be seen as one of the legacies of central planning and socialism. 'The impact of central planning over the Siberian economy has also been a topic for studies (for example, Brock 1999). Among the legacies, the asymmetric industrialization with territorial production complexes at its heart was of special incerest in the wake of Siberia's transformation (De Souze 1989; Bandrnan and Linge 1921). These problems in the 1990 s were rather obsolete: and the changes of the inherited industry structure became an important issue. In this respect, the conversion of the military industry to civilian production gained particular artention (sec Opitz 1993; Musicnko 1994; Amoscnok and Bazhanov 1994). Today, conversion is party achieved. Other parts of the Siberian armament industry survived and found new and attractive markets for cheir products.

With the transformarion of the political and economic system, the industry structure distorted by political decision-making was affected and the old social safety net based on company welfarc and full employment broke down (see Meck 1994). Siberia's social transtormation consisted of a number of problems, including migration, the eceline and transformation of the urban sxial enviromment, educational problems, 
and foremost, the redefinicion of space and identity in space for its indigenous and actual population. Industrial policy and the wage structure of the centrally planned Soviet Union led to migratory flows to Siberia for strategic and economic rcasons, the trend partly reversed during its transformation. Consequently, migration became an important issue (see Sutherland and Hanson 2000; Heleniak 1995 , 1997), especially the depopulation of Northern Siberia (sec Göler 2002; Heleniak 1999). Migration was even seen as the central issue for Siberia's economic revitalization, as the population patterns achicved in the Soviet times are a major hurdle to urilizing Siberia's natural resource endowment (Gaddy and Hill 2003). Cities, which often had been lasge industrial-plants-cum-housing, had to be redefined and the social attractiveness of cities measured (Portnov 1998). The decline of state-sponsored education facilities, most prominently Akademogorodok, had a far reaching impact also on the quality of life and migration (Castells and Hall 1994).

More than just changing welfare provisions, transformation also led to a renewed debate on the identicy of Siberia: was it still Russia, and dicd it belong to the narive (indigenous) people? Or was it a part of Northeast Asia (at least the Far East)? Thesc were some of the questions debated (see Kotkin and Wolff 1995; Fondahl 1996). The role of indigenous people, their identity and rights regarding the enviromment and resources (Heintze 1993; Anderson 2002), and their formation in the new society (Yakimov and Morrison 1995) were discussed from anthropological and sociological points of view, but the political and economical topic of Siberian separatism was also touched upon (Chichlo 199/4). Additionally, the tole of minorities in Sibcria resulting from the Stalin's policy overpopulation was addressed (see Klüter 1992).

Transportation was one of Siberia's problems that originated since the original conquest of Siberia in the sixteenth century, later resulting in the construction of one of the world's largest transportation routes, the Trans-Siberian railway (TSR). Sovict central planning left a difficult legacy in form of the BAM (Reymann 1992). However, the vision of Siberia as a transport corridor for goods from East to West and vice versa was very attractive, as well as the transport of Siberian resources to both regions. For Europe, this especially meant energy transport (see Meinhart et al. 2002). Since the first signs of opening in Nortb Korea, there was much discussion about the link to the East and the realization of the "iron silk road," linking Europe and East Asia's trading nations (Korca, Japan, and China) through the Trans-Korean-railway (TKR), Trans-Mongolian-railway (TMR), and TransSiberian railway (TSR) (see Lee 2001; Simonia 2001). This still remains a vague concept full of technical, conomic, and political problems.

This brief review of existing literature shows that Western research and the debate over Siberia's development raised a number of questions as well as provided a number of answers. The rescarch, however, was dominated by resources (and to a smaller cxtent, industrial), economic, geographic, sociological, and anthro. pological sectors. 'The turn towards institutional economics, characteristic of the 
transformation debate in Central and Eastern Europe as well as Russian central state, did not take place. Some of the issues that could be addressed in such a debate are discussed in the following section.

\section{MICRO AND MICRO-INSTITUTIONAL FACTORS IN SIBERIAN ECONOMIC DFVELOPMENT}

The transformation of Russia's economic system and the dismantling of central planning, while beginning in earnest some years latcr than in Central and Eastern Europe, followed a similar pattern in Siberia. Several central planning legacies needed to be overcome: 1) economic priorities changed from the over-emphasis of heavy industry to a consumer-oriented econonyy ${ }^{8}$; 2) the old pattern of extensive growth led to a dead end; and 3) the industrial structure suffered from degradacion and economic obsolescence. There was a considerable rechnological gap with to OECD countries, but the greatest challenge was the change from the Soviet burcaucratic socicty and incentive system to a market economy system characterized by entrepreneurship; fron the bomo smiteticus to the bom alsens of the marker economy (see Seliger 2000).

In transformation, especially in the early blueprints of refurmers and international agencies, the challenges were underestimated. Whilc liberalization and deregulation proceeded according to faster ("shock therapy") or slower ("gradualism") designs, the institutional structure necessary for the market economy did not develop - instead, Russia ended in a "bad institutional equilibrium" (Sutcla 2001)." The state was on the one hand too strong, i.e., still too involved in the economy via intervention and the bureaurracy, and on the other hand it was roo wenk, meaning that there was a low degree of law enforcement lading to high uncertainty. Fisicson $(2000,7)$ speaks of the "re-feudalisation" of the Russian economy. Salient features include: traditional forms of legitimating power; a weak center; strong lucal authorities without the devclopment of a system of proper decentralization; networks of fealty and obligation reducing uncertainty; and markets only existing on the margins and monopolized or closely regulated by local authorities. Furthermore, discretion of authoritics with teyard to the law is great, property rights are diffuse, and power is personalized and not functional.

The unexpected manncr of transformation led to a reconsideration of reforming tasks at the contral level as well as at the level of center-region relations. At the central level, the necessity of a political system characterized by the scpatation of power (for example, in the long-lasting conflict about monetary policy), transparency (especially in privatization policy), and competition became clear, also showing ways for policy reform (sec contributions in Welfens 2002). The pivotal role of institutions in state transformation is accepeed now and difficulties in implementing institutional changes found increased attention (see Seliget 2002). In addition to 
changes at the central state level, the relationship between the center and regions, the emerging system of federalism, and the emerging economic structure in space was of particular academic interest. Studies of the relationship between political power and regional economic change (see the early contribution of Hanson 1994) pointed out the impact of institutions on economic development. Other studies included the localization of Russia (Müler 1997; Stavrakis et al. 1997), and there was even a trend rowards a "Russia of the regions" (Nicholson 1999), leading to a new spatial economic structure (sce Harter and Faster 2000). Russian federalism however, was highly uneven berween strong and woak rcgions and problems regarding federalisn increased (Kirkoy 1998, Schneider 1999). Fiscal relations to the center were a bone of contention (see Kouznetsova et al. 1999). Competition among regions could not work in a beneficial way (1 Iermann Pillath 2000), sincc Russian fceteralisn was "market distorting" (Eckhardt 2002) and highly asymmetric, with some regions gaining almost complete autonomy from the center and ochers still in the center's grip due to the regional power balance.

Relatively few studies are conserned with Siberia's regionalization (an exception is Stadelbauer 1996; for the Novosibirsk rcgion, Kirkov 1997). Regarding institutional changes, only the Siberian agreement with the prospect of complete institutional reorganization gained some attention (Hughes 1994). Thornton (2002) discusses institutional change in the Russian Far East. One of the most interesting studics of institutional change on the regional level is that of Stack (1998), which makes a comparison of historical and evolutionary neo-institutionalized explanations for regional change. Stack (1998) identifies threc institutions related to rent secking that concrged in the Russian regions due to incomplete transformation towards at market economy: 1) the new regions act as kyak "roof", granting protection to rents of constituents); 2) hazjain, or "boss" (using selective incentives to organize constituents for its benefic, i.e., to extract rents from constituents); and constituents again work as tyl (back-up, support for the region's lobbying efforts). In addition to conflicts with the center, cunflicts typically occurred around the Siberian regions. This existed in almost all the analyzed regions, mainly concerning federal and regional shares of taxes. The two major conflicts between various forms conflict were those of regional organization (for example, krai and autonomous okmg with their tespective property rights for industrics) and conflicts about border policies in the Far East.

Stack (1998) is mainly preoccupied with Siberian regions pointing to the direction of rescarch the institutional development of Siberian regions. ${ }^{10}$ This analysis can be broken down into three groups of questions, namely: 1) questions of globalization and geo-economics relevant to the region; 2) the analysis of macro-institutional factors affecting the regrions; and 3 ; the analysis of micro-institutional, regional factors. The first group of factors include the incernational trade integration of Sibctian regions, which is especially important for the Far Eastern region (Valencia 1995; and Seliger 1999). The roles of resources, production processes, and trans-na- 
tional location competition need to be included. The impact of geopolitical and geo-economic factors, including federal foreign policy, is high for border regions and regions with rich resources. Therefore, the understanding of regional institutional development is relevant, but foreign policies of the regions, which became important since the mid-1990s, should be also analyzed (see the overview for Russia, Melvin 1996).

Among the macro-institutional factors affecting the region, the general direction of federal economic policy was the center of the transformation (the market economy and its specific types). The emergence at the center needs to be understood. Secondly, the legal basis and actual enforcement of center-region relations should be included, as well as the center's financial system and the emerging system of fiscal federalism. Enforcenent of new legislation in the regional context has often been one of the weak links in the Russian federal system. Re-centralization under Putin reduced this problem ro some extent, but led to the new problem of the restriction of autonomous regional development.

The last, and until now, the mostly neglected group of factors could be called micro-institutional factors. This refers to emerging institutional arrangements at the regional level. It has been pointed out in the transformation theory debate that the development and impact of formal institutions can only be understood when seen in relation to informal institutions and cultural embedded-ness. This is even truer at the regional level than the national level. Siberia sometimes looses relations to the center and the large number of autonomous and semi-autonomous sub-regions, the latter group's backgrounds varying culturally, ethrically, and historically. The climatic and gcopolitical differences of its sub-regions developed a rich variety of jeliosyncratic instilutional features. Stack's (1998) analysis touched on some of these factors, but otbers such as regional educational systems, regional judicial systems, and the process of elite circulation (incliding indigenous elites, Soviet elites, mafia, and new entrepreneurs) can be useful in such an analysis.

While the above factors relate to a positive analysis of the regional institutional structure: normative conclusions can be drawn from such an analysis. Successful regional arrangements can be identified and a system for interregional competition can be designed. which allows for and forces regions to learn from other successful regions (in a process of regional institutional innovation and imitation).

\section{N. CONCLUSION}

The new agenda for research described in the preceding paragraphs should not be seen as a complete departure from the reviewed research, but rather points to an integration of existing rescarch with grcatcr emphasis on micro-insticutional factors. This reseatch does not aim to result in another grand design for Siberian economic development. Instcad, is aims to understand the variety of regional and 
sub-regional economic outcomes of various regional and sub-regional institutional arrangements. While initial conditions such as the resource base are fixed points of such an analysis, the analysis of institutional arrangements at the regional level is insofar more rewarding and could result in policy implications, as it conccrns variables of regional development. What is more necessary are studies on the local and sub-regional level that are integrated in a greater regional study (for examyle, for the threc Sibcrias) and related to grcat topics of the central state (transformation and asymmetric federalism). This research program does not exclude particular researchers of Siberia, Western or Russian. Instead, new research can contribute to the numerous studies of the former group, with the latter's closer understanding of local and regional circumstances.

\section{REFERENCES}

American Universiry. 1996a. Siberia Nuclear Waste. Available: http://www american. edu/projecrs/mandala/TED/sibnuke.litm.

. 1996b. Siberia Nuclear Pollution. Available: http//www.american.edu/ projects/mandala/TED/sibnuke.htm.

Amosenok. Filla and Vicror Bazhanov. 1994. Specific Features of Conversion in Siberian Defence Enterprises. In Adjustment Processes in Russian Defince Enterprises within the Framework of Conversion and Transition, eds. Petra Opitz and Wolfgang Pfaffenberger. Münster: LIT.

Anderson, D. 2002. Entitlements, ldentity and Time. Addressing Aboriginal Rights and Nature Protection in Siberia's New Resource Colonies. In Peaple and the Land: Patbways to Reform in Post Soviat Sibiria, ed. Erich Kasten. Berlin: Reimer.

Astrov, Vasily. 2003. The Russian Oil and Gas Sector: Facing the New Challenges. Forscbungsherichte No. 294. Wien: Wiener Institut fuer Internationale Wirtschaftsvergleiche.

Backman, Charles A. 1999. The Siberian Forest Sector: Challenges and Prospects. Post-Soviet Geograpby and Economics 40(6): 453-569).

Backman, Charles A. and Vadim K. Zausaev, 1998. The Forest Sector of the Russian Far East. Post Sintet Geograpby and Economics 39(1): 45-62.

Baden, John A. 1994. Anerica's Earth Day Supergift: Siberia, Foundation for Research on Economics and the Environment (FREE). Available: http://www.free-eco. org/pub/Siberia 44 html.

Bandtenan, M.K. and G.J.R. I.inge. 1991. Siberian Territurial Producation Complexes and Soviet Economic Planning. In The State and the Spatial Management of Industrial Change, cds. D.C. Rich and G.J.R. Linge. I.ondon: Routledge.

Biggar, Darryl. 2002. Reform of Gas Scctor in Russia. OECD journal of competition law and policy 4(2): 147-63.

Blasi, J.R, M. Kroumova, and 1. Kruse. 1997. Kremlin Capitalism: The Privatization 
of the Russian Liconomy. Ithaca: ILR Press.

Blauberg, K. 1995. Siberian Forest Sector GIS Database. IIASA Working Paper XP-y5-012. Laxenburg: IIASA.

Bøhmer, Nils and Thomas Nilsen. 1995. Reproccessing Plants in Siberia. Bellona Foundation Working Paper No. 4.

Bond, Andrew R. and Richard M. Levine. 2001. Noril'sk Nickel and Russian Platinum-Group Metals Production. Post Soviet Geography and Economics $42(2)$ (March): 77-103.

Bradshaw, Michael. 1992. Siberia Poses a Challenge to Russian Federalism. RFE/ RL Research Report 1(41) (October 16): 6-14.

Bradshaw, M.J. and N.J. Lynn, 1996. Resource-based Development: What Chance for the Russian Far East? Russian Regional Research Group Working Paper Scrics. University of Birmingham.

Brock, Gregory J. 1999. Exploring a Regional Technical Efficiency Frontier in the Former USSR. Fionomics of Planning 32: 23-44.

Bychkova Jordan, B., Jordan Bychkov, and R.T. Holz. Post-Soviet Change in a Yakutian Farm Village. Erdkunde 52(3): 219-31.

Castells, Manuel and Peter Hall. 1994. Science City Blues. Innovation by Design? The Siberian Dream: Akarlemgorodok. Teibmopoles of the World. London: Routledye.

Chichlo, Boris P. 1994. Deux Visages du Séparatisme Sibérien. Revue des Etudes Slaves 64(1): 165-78.

Considine, Jennifer 1. and William A. Kerr. 2002. The Kussian Oil Economy. Cheleenham: Elgar.

De Souza, P. 1989. Territorial Production Complexes in the Soviet Union-with Special Fous on Siberia. University of Gothenburg.

Dicnes, Leslie, Istvan Dobozi, and Marian Raderki. 1994. Energy and Econonic Refurm in the Forner Soniet Union: Implications for Production. Comsumption and Fxports, and for the International Energ\}. Markets. Basingstoke: Macmillan.

Dobretsov, N.L., A.E. Kontorovich, A.G. Korzhuthacv, V.V. Kuleshov, V.le. Seliverstov, and V.I. Suslov. 2001. Scientific Basis for Strategy of the Socialeconomic Development of Siberia. Economics and Sociology Vol. 4: 35-100.

Eckardt, Scbastian. 2002. Russia's Market Distorting Federalism: Decentralisation, Governance, and Econonic Pcrformance in Russia in the 1990s. Discussion Papers of the Osteuropa-Institut der Freien Universitä Berlin, Arbeitsbereich Politik und Gesellschaft Nr. 42. Berlin: Osteuropa-Institut.

Ericson, R.F. 2000. The Post-Soviet Russian Fconomic System: An Industrial Feudalism? BOFIT Online No. 8. Helsinki: BOFIT.

European Space Agency. 2003. Mapping the Siherian Forests. Available: http://www. esa.intiexportiesaC.P/GGG93AZTGEC_Protecting_0.html

Flück, R. 1996. Baikalsee; Einc Literaturdokumentation zur Umweltsituation am Baikalsee. Dokumentation Natur und Landschaft No. 21.

Fondahl, Gail. 1993. Siberia: Native Peoples and Newcomers in Collision. In Nations 
and Politics in the Soviet Successor States, eds. Ian Bremmer and Ray Taras. Cambridge: Cambridge University Press.

Fondahl, Gail A. 1996. Contested Terrain: Changing Boundaries and Identitics in Southeastern Sibcria. Post-Sonit Guosrably and Lonomics 37(1): 3-15.

Forbes, B.C. 1999. Land Use and Climate Clange in the Yamal-Nenets Region of Northwest Siberia: Some Foological and Socio-economic Implicarions. Polar Rescarch 18(2): 1-7.

Frühauf, M. and T. Meincl. 2003. Geoökologische Folgen der Sowjerischen 'Neulandgewinnung' in Sïdsibirien. Geno'kn 24(1-2): 203-28.

Gavigan, Robert J. 1996. Siberia's Environment: A Challenge to Traditional Thinking. The Geurgetoun Intematimal Enirommental Law Reviow 8(2).

Gaddy, Clifford G. and Fiona Hill. 2003. The Siberian Carse: How Commmist Planners Left Rusiza Out in the Cold. Washington, D.C.: Brookings Institution Press.

Gerloff, J. 1994. Nuteung und Gefährdung Borealer Waldlandschaften Sibiriens. Essener Geographische drbeiten Vol. 25: 59.78.

Göler, D. 2002. Rückzug aus der Nördlichen Peripherie. Räumliche Konsequenzen der Abwanderung aus dem Ilohen Norden Sibiriens. Praxis Gographie 32(1): $10-13$.

Habeck, J. 2002. How to Turn a Reindeer Pasture into an Oil Well, and vice versa. Transfer of Land, Compensation and Reclamation in the Komi Republic. In People and the Land: Pathways to Reform in Post Sonizt Siberia, ed. Erich Kasten. Berlin: Reimer.

Hanson, Philip. 1994. Regions, Lacal Power and Economic Change in Rzssia. London: The Royal Institute of International Affairs.

Hatter. Stclanie and Gerald Easter. 2000. Sbaping the Economic Spate in Russia. Aldershot: Ashgate.

Heinrich, Andreas, Julia Kurenit, and Heiko Pleines. 2002. Forcign Investment and National Interests in the Russian Oil and Gas Industry. Post-communit Fonomies 13(4): $495-507$.

Heintze, H-J. 1993. The Protection of Indigenous Peoples under the ILO Convention. In Amazonia and Siberia: Legal Aspects of the Preservation of the Environment and Detelopment in the Last Open Spate. eds. M. Bothe, 'I. Kurzidem, and C. Schmidt. London: Graham and Trotman.

Heleniak, Timothy E. 1995. Economic Transition and Demographic Change in Russia: 1989-1995. Post-Soviut gengruphy 36(7): 116-58.

1997. Internal Migration in Russia during the Fcomomic Transition.

Port-Suriet Gergotphy and Fronomiar 38(2):81-104.

1999. Out migration and Depopulation of the Russian North during the 1990s. Part-Soviot Gograpby and Economics 40(3): 155-205.

Herrmann-Pillath, Carsten. 2000. The Relation between Federal Government and Regions in the Russian Federation: the Perspective of Competitive Federalism and Recommendations for Reform. Wittener Diskussionspapiere Nr. 67. Witten: 
Fakultä für Wirtschaftswissenschaften.

Hughes, James. 1994. Regionalism in Russia: The Rise and Fall of Siberian Agrcement. Europe Alia Studies $16(7)$ : 1133-61.

Initiative for Sxial Action and Renewal in Eurrasia (ISAR). 2003. Siberia's Envimnmental Mivement (Spring). Give \& Take.

Karrasch, H. 1995. Sibirien: N'aturressourcen, Nutzungsprobleme, Zukunftsperspektiven. HGG-Journal Vol. 9: 76-93.

Kirkow, Peter. 1997. Economic Change in Novosibirsk Province: from Depressed Rust Belt to Siberias Financial and Distributional Centre. Kussian Regional Research Group Working Paper Series. Liniversity of Birmingham.

- 1998. Russia's Provinies: Auborilarian Tranjformation versus Lacal Aulonomy? New York: St. Martin's Press.

Klüter, H. 1992. Regional Autonomy or Emigration - The Situation of the Germans in Sibcria. Geographiscbe Zeitschrift 80(3): 139-18.

Klüter, Helmut. 1994. Sibirien und Kasachscan, Zwei Konkurrierende Rohscoffproduzenten. Geographishe Rundschau Jg. 46, Heft 4, S: 208-15.

Kotkin, Stephen and David Wolff, eds. 1995. Redisovering Rusia in Asia: Siberia and the Russian Far East. New York: M.E. Sharpe.

Kouznetsova, Olga, Philip Hanson, and Douglas Sutherland. 1999. Reforming

Centre-Region Budgetary Relations in Russia. Russian Regional Research Group Working Paper Series No. 17. Brimingham: School of Geography and Environmental Sciences and Centre for Russian and East European Studies.

Lane, David. 1999. The Political Ecrnomy of Rusizm Oil. Lanharn: Rowman \& Littlefield. Lec, Jac-Young. 2001. The Trans-Siberian Bridge: Activation Opportunities. Interperisdica 12(6): 644-48.

I.juhto, Kari. 2001. Russian Gas and Oil Giants Conquer Markets in the West: Fvidence on the Internationalization of Gazprom and LIKK Oil. Jotimul of East-Weit Business 7(3): $31-72$.

Locatelli, Catherine. Les Concraintes de la Politique D'exportation Gaziere de la Russic. Revne de L'energie 53(535): 141-52.

Lynn, N.J. 1996. The Resource Base of the Russian Far East: the Potential for Regional Development? Russian Regional Research Group Working Paper Series. Eniversity of Birmingham.

Makarydrev, Andrei S. 2000 . Islands of Globalization: Regional Russia and the Outside World. Working Paper No. 2. Zürich: Center for Security Studies and Conflict Research.

Milanovic, B. 1997. Income, Inequality, and Poverty during the Transition from Planned to Market Esonomy. Washington, D.C.: World Bank.

Meek, James. 1994. Siberia Loses its Soviet Safery Net. The Guardian (October 15).

Meinhart, Berit, Christian von Hirschhausen, and Andreas Chollet. 2002. Russische Gasexporte in dic EU: Optionen unter Einbeziehung der Transitlaender Ukraine 
und Belarus. Energiewirtsibaftiche' Tagesfragen 52(12): 814-17.

Mclvin, Neil. 1996. Regional Foreign Policies in the Russian Federation, Iondon: Royal Institute of International Affairs, Post-Sovier Business Forum.

Morse, Edward L. and James Richard. 2002. The Battle for Energy Dominance. Foreign Affairs 81(2): 16-31.

Müller, Diermar. 1997. Regionalisierung des Post-sowjetischen Raumes, Arbeitspapier Nr. 6. Berlin: Osteuropa-Instirut der Freien IIniversität Berlin.

Murray, W.E. 1997a. Natural Resources in the Pacific-Asia Region: A Selected Bibliography. Russian Regional Rescarch Group Working Paper Series. University of Birmingham

1997b. Forestry and Fisheries in Pacific-Asia Resource Depletion, Import Dependence and Potential Implication for the Russian Far last. Russian Regional Research Group Working Paper Series. Liniversity of Birmingham. Mursaly, W.F. and M.J. Bradshaw. 1997. Rising I'cnsions in the Natural Resource Markets of Pacific Asia and the Role of the Russian Far East: Focus on Energy. Russian Regional Research Group) Working Paper Scries. University of Birmingham. Musienko, Ignr. 199.1. Management Behaviour in Siberian Defence Enterprises. In Alinstment Processes in Russian Defence Enteptises within the Frameunte of Comersion and Tranition, eds. Petra Optiz and Wolfgang Pfaffenberger. Münster: IIT. Nicholson, Martin. 1999. Lowards a Kuisia of the Regions. Oxford: Oxford Lniversity Press.

Nilsson. S., A. Slwidenko, and K. Blauberg, eds. 1996. Small Siberian Forest Atlas. IIASA Working Paper W'P-96-151. Laxenburg: IlASA.

Obersteiner, M. 1995. Status and Structure of the Forest Industry in Siberia, II $\Lambda$ SA Working Paper XP-95-030. Laxenburg: II $\Lambda \mathrm{SA}$.

19)8a. A Model for the Siberian Timber Products Market: An Enginecting-Economic Approach. IIASA Working Paper XP-98-034. Laxenburg: IIASA.

1998b. Siberia and Far East Russia's Future Wood Supply: An Analysis. 1lASA Working Paper IR-98-001. Laxenburg: IIASA.

Opitz, Petra. 1993. Chancen Regionaler Rüstungskonversion in Russland, Die Regionen St. Petersburg und Novosibirsk, Berichte des Bundesinstituts für Ostwissenschaftliche und Internationale Studien Nr. 39. Köln: Bundesinstitut für Ostwissenschaftliche und Internationalc Studien.

Opp, C. and 1). Haase. 2000. Goökologie in der Entwicklungszusammenarbeit. Geoökologische İntersuchungen zum Boden und Gewïsserschutz in Südsibirico und in der Mongolei. Proceedings 52. Deutscher Geographentag Hamburg 1999.

Portnov, Boris A. 1998. Social Attractiveness of the Urban Physical Environment:

Citics of Siberia. The Annals of Regional Science Vol. 32: 525-18.

Rcymann, Sybille. 1992. Dic BAM -- cin Großprojekt der Sowjetwirtschaft vor dem Hintergrund von Perestrojka und der Erstarkung der Republiken. Osteuropa Wintschaft $37(1): 77-92$. 
Robinson, Paul and Gary Cook. The Gold and Utanium Mines of Siberia, Where Problems with Radioactivity Really Begin in Russia. Available: http://nwwiearthisland orgiproject reportPage 2.cfmireportconcentID-13\&sub SireID - 1 kpageID $=71$

Sagers, Matthew. 1995. Prospects for Oil and Gas Development in Russia's Sakhalin Oblast. Posi-Soriet Geograpby 36(5): $274-90$.

Sagers, Matthew J. 2001. Developmenes in Russian Crude Oil Production in 2000. Post-Sriviet Geograpby and Eonomitis 42(3): 153-201.

Schrnullius, $C$. and W. Wagner. 2000). SIBERIA - Kartierung Borcaler Walder mit Radarfernerkundung. Ciegraphisebe Rundschan 52(12): /4-49).

Schneider, Eberthard. 1999. Probleme des Födcralismus in Russland. Bericht Nr. 21. Köln: Bundesinstitut für Ostwissenschaftiche und Internationale Studien. . 2000. Putins Rezentralisierungsinitiativen. Aktuclle Analyse Nr. 29.

Köln: Bundesinstitut für Ostwissenschaftliche und Internationale Studien.

Seliger, Bernhard. 1999. The Double Integrarion: Siberia as part of Russia and Siberia as Part of North East Asia. Paper presented at the International Conference, Kelations between Kotean and Siberia, Korean-Siberian Economic Association, Seoul, November 27, Conference Proceedings.

. 2000. Entreprenetrial Actitity, 'Transition and Development - Some

Lessons from Cental and Eastem Europe, 1999 Ycarbook of llankuk Liniversity of Toreign Studies. Seoul: HUIS Ptess.

2002. Towards a More Crencral Theory of Trinsformation. Eastern Ezropean Fionomios $10(1)$ : 36-62.

2004. The impact of Globalization ... Chances and Risks for Russia

as a Transformation Country. Fatiem Eumpean Fommics 42(1) (Januar/ Fehruar): 5-24.

Shulga, Arina. 2001. Foreign lnvesement in Russia's Oil and Gas: Lcgal Framework and lessons for the Future. Joumal of International Economit Law 22(4): 1067-1103. Simusia, Noxdari A. 2001. 'IKR-ISR Lirkage and les Impact on ROK-DPRK-Russia Relationship. Journal of least Asian Aflaim 15(2): 180-202.

Smirnov. Nikolai E. 1994. Unmweltpolitische Instrumente für die Erdölindustrie in Westsibirion. Münster: Lit-Verlag.

Stack, Graham. 1998. Ncoinstiturionalist Perspectives on Regionalisation in Russia, Discussion Papers of the Osteuropa-Institut der Freien IJniversität Berlin, Arbeitsbereich Politik und Gesellschaft Nt. 21. Berlin: Ostcuropa-Institut.

Stadelbauer, Jörg. 1996. Recrionen und Regionalismus in Sibirien und Ural. In Ragionalismws und Nationalismui in Rusland, hrsg. Andrcas Kappeler. Baden-Baden: Nomos, S.

Stavrakis, Peter J. Joan Debardeleten, and Larry Black. 1997. Beyond the Monolith:

The Emerente of Regionalism in Post-Sonit Russia. Washington, D.C.: Woodrow Wilson Conter Press.

Stre'iezki, Wladimir. 2000. Desintegrationsrisiket und neut Regrionalstrategic in 
Russland. Bericht Nr. 9. Köla: Bundesinstitut für Ostwisserschaftliche und Intemationale Studien.

Sutcla, P. 2001. Putin's Sccond Year - and Beyond. Russian Economy, the Month in Review No. 5: 1.

Sutherland: Douglas and Philip Hanson. 2000. Demographic Responses to Regional Fconomic Change: Inter-Regional Migration. In Regional Fimnomic Cbange in Russiat, eds. Philip Hanson and Michael Bradshaw. Cheltenham: Edward Elgar.

'Ianneberger, Thomas. 1997. Landwircschaftliche Lntcrnchmensentwicklung im Transformationsprozel3 der Russischen Wirtschaft, Beispiel einer Kolchosgenossenschaft in der Kulunda-Steppe/Westsibiricn, Berliner Beiträge zum Genossenschaftswescen 33. Berlin: Institut für Genossenschuftswesen an der llumboldt- Universität zu Berlin.

Thornton, Judith. 2001. Institutional and Structural Change in Pacific Russia. Comparative Fconomic Studies 43(1): 1-8.

Valencia, Mark. 1995. The Russian Far Fast in Transition: Oppsptunities for Regrional Economic Cooperation. Boulder. CO: Westview Press.

Wein, Norbert. 1996a. Die Westsibirische Erdyasregion, Erschließung und Weiterer Vorstol3 in den Norden. Die Erde No. 127; 159-75.

-1996b. Die Westsibirische Erdölprovinz: von der "Boom-Region" zum Problemgebiet. Gengraphische Rundsctan 48(6): 380-87.

2002. Das Baikalsee-Okosystem. Gevgraphische Rundschaul 54(1): 48-54.

Welfens, Paul J.J. 2002. Transformationskrise und Netue Wirtschaftssefformen in Russland. Heidelberg: Physicat-Verl.

Wilson, E. 2002. Est' Zakon, Est' i Swoi Zakkony: L.cgal and Moral Finritlements to the Fish Resources of Nyski Bay, North-Fastern Sakhalin. In People and the land: Puthiay: tn Refirm in Poit Siniet Siberia, ed. Erich Kasten. Berlin: Reimer. Yakimov, O.D. and J.F. Morrison. 1995. The National Press of the Indigenous Pcoples of Siberia: Origins and Future Directions. European Joumal of Communication $10(1): 109-26$.

Ziker, J. 2002. Land Use and Economic Change among the Dolgan and Nganasan. In People and the Land: Patbways to Reform in Post Sinizt Siberia, cd. Erich Kasten. Berlin: Reimer. 


\section{ENDNOTES}

1 For the lest theee demands, it is important th recall the Rissian distinction between the two silytias and the Far East isee Bradshaw 1992) regional strategies for the two wil. difier.

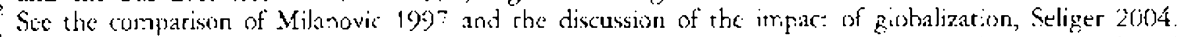
:Agair. it wot:!] be wrong to spak of a matket econony in a Western sense. Obscrvers spoke of

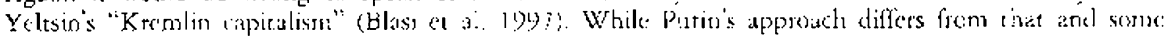

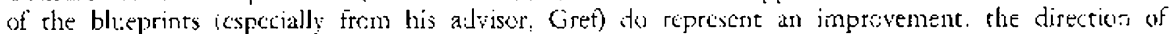

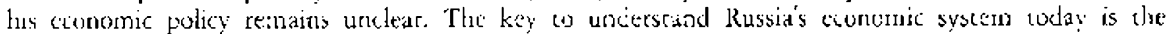

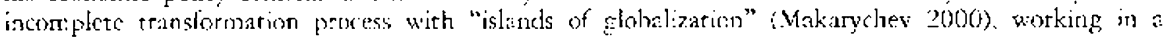
market environment, and the iarge: untanstorred remainder of the country.

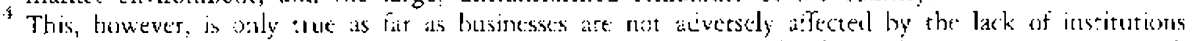

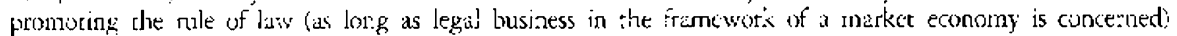
and the lack of an appropriate minastructure.

This paper docs nor ate:mpe ro define "Western" w such a soncept. The ourlook of American scicritists working in a government think sank on resources might be very difforetit from chat of a British schulat

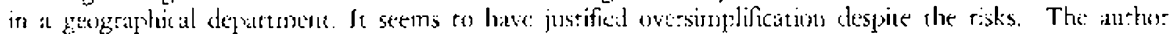
presents a rentency of "Wester:" research. Among the rescarch, an impirtant pare is done by the Russian researchers in Western rescarch insticuess. At ale same rime, this article docs rot clation 10 review al: publications on Silheria, but gives an ovenview of the mose important issues.

"This does nor say that a ficus on problems of reziona. develepmen always takes the form describeci

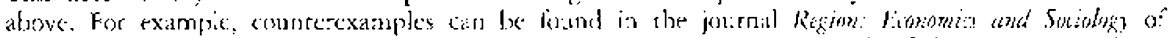
che Institure of Ficunomics and Indusirial Engimeering of the Siberian Branch of the Russian deadeny - of sciuce.

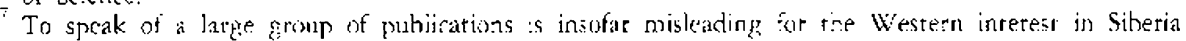
is generaliy small. Ot the fifty-seven publications listed with the seywort "Silveria" in the Getman

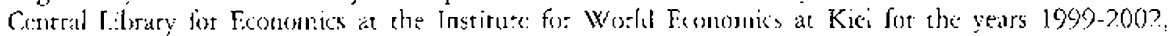

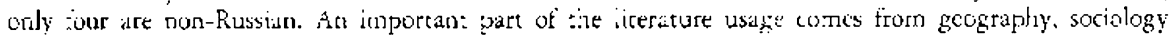

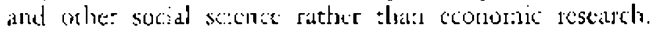

"Military spencing alone (excluding the rosts tor persomel) reaches up a 1 ? of of GDP. Additionally.

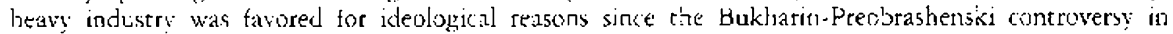

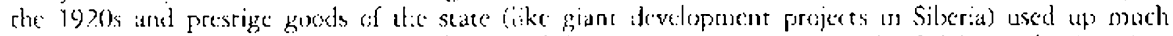
0 the investrent. The muse positive feature of tivis restrucruring as that the fall is production since

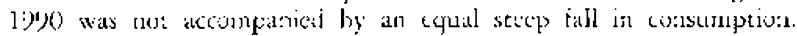

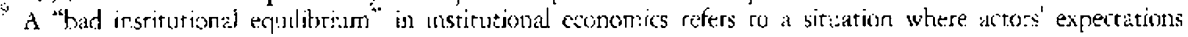

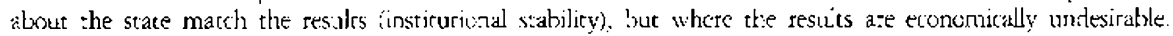

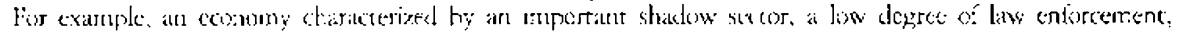
demenetizacion: and low CiDP growth rates.

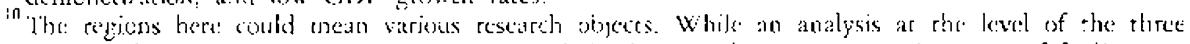

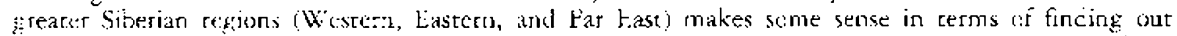

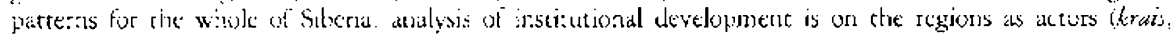
abkits: and ak: riag? 